\title{
Yol ve Yolculuk Bağlamında Nalan Barbarosoğlu'nun Yol Işıkları Eseri
}

\section{YAŞAR ŞIMŞEK*}

\begin{abstract}
ÖZ
Yol ve yolculuk, farklı sanat türlerinde olduğu gibi edebî türler içinde de geçmişten bugüne kullanılan başlıca temalardan biri olmuştur. İlk sözlü ürünler destan, masal gibi anlatı türleri başta olmak üzere bugünün öykü, roman gibi türlerinin de temasını teşkil eden yol ve yolculuk; değişim, arayış, kaçış, keşif, sevgiliye kavuşma gibi amaçları ihtiva eder. Modern zamanlarda bu kavramlar bireyin kimlik bunalımını, yalnızlığını, iletişimsizliğini, kaçma arzusunu ve içsel sorunlarını simgeleyen bir metafora dönüşür. 1990 sonrası Türk öykücülüğünün önemli yazarlarından biri olan Nalan Barbarosoğlu, bireyi temel alan öykülerinde kurguya dâhil ettiği kişiler düzleminde yol ve yolculuk temasını işler. Yazarın Yol Işıkları öykü kitabı da bu anlamda dikkati çeken bir eserdir. Bu çalışmada Barbarosoğlu'nun Yol Işıkları eserinde yer alan öyküler yol ve yolculuk teması bakımından incelenecektir. Öykü karakterlerinin gerek iç konuşmaları gerekse çevreyle kurdukları ilişkiler bağlamında arayışları, çıkmazları, çırpınışları, kırılganlıkları, yalnızlıkları, tutunamayışları, umutları ve umutsuzlukları üzerinden yol ve yolculuk temasının izi sürülecektir. Özellikle öykülerde yazarın yol ve yolculuk temasıyla ilgili göndermelerinin nelere karşılık geldiği, neyi imlediği üzerinde durularak öykülerdeki kişilerin toplum/aile/ arkadaş çevresindeki konumlarına açıklık getirilecektir. Ayrıca, öykülerin süregelen hayatla bağdaşan/bağdaşmayan yönlerine değinilerek yol ve yolculuk kavramlarının anlatılarda ne ölçüde somutlaştırıldı̆̆ gösterilmeye çalış1lacaktır.
\end{abstract}

Anahtar sözcükler: Yol, Yolculuk, Tema, Nalan Barbarosoğlu, Yol Işıklart

* Öğr. Gör. Dr. Gaziosmanpaşa Üniversitesi, Eğitim Fakültesi, Türkçe Eğitimi Anabilim Dalı, Tokat/ Türkiye E-posta: yasar.simsek@gop.edu.tr

Makale Gönderim Tarihi: 17.10.2017 • Makale Kabul Tarihi: 30.11.2017 


\section{ABSTRACT \\ Nalan Barbarosoğlu's Yol Isıkları Work in The Context of Road and Journey}

The road and journey are among the main themes that have been used in the literary genres from past to present, as they are in different kinds of arts. Mainly narrative types such as epic and tale, which are first verbal products, the road and journey that form the theme of today's story and novel contain purposes like change, search, escape, discovery and joining lovers. In modern times, these concepts transform into a metaphor symbolizing the individual's identity crisis, loneliness, lack of communication, desire to escape and internal problems. Nalan Barbarosoglu, one of the most important authors of the Turkish storytelling after 1990, process the subject of the road and journey about the people involved in fiction in her stories based on the individual. Yol Isıkları story book of the author is a remarkable work in this sense. The stories in Barbarosoglu's Yol Isıkları will be examined in terms of road and journey. The trail of the theme of the road and journey will be followed through of story characters search, dilemmas, clashes, fragilities, loneliness, inability to hold, hopes and hopelesness in the context of both internal conversation and the relationship they establish with the environment. Especially in the anecdotes, it will be clarified to what positions the authors correspond to the subjects related to the theme of road and journey, what they refer to, and the positions of the people in the society / family / friend environment. In addition, it will be tried to show how the concepts of the road and journey are embodied in the accounts by referring to the aspects of the stories that are compatible with the ongoing life.

Keywords: Road, Journey, Theme, Nalan Barbarosoglu, Yol Isıkları

$\dot{\mathrm{I}}$ nsanlık tarihinin önemli meselelerinden olan yol ve yolculuk kavramları geleneksel düşünce ve sanat dünyasında olduğu gibi modern/çağdaş düşünce ve sanat dünyasında da geniş yer tutar. Edebiyattan sinemaya, resimden mimariye, müzikten tiyatroya farklı sanat dallarında işlenen yol ve yolculuk temaları aynı zamanda döneminin kültürel, tarihsel ve toplumsal atmosferini yansıtan bir unsurdur. Bazı sanat eserlerinin temel dayanağını oluşturan yol/ yolculuk teması aynı zamanda arketip, motif ve sembol gibi niteliklere sahip bir olgudur. Bu nedenle her dönemde farklı tutumlarla, bakış açılarıyla işlenmiş, insanın doğasını yansıtması açısından sanatçıların üzerinde durdukları bir mesele olmuştur. Dünya edebiyatında olduğu gibi Türk edebiyatında da yol ve yolculuk, hem geleneksel anlatı türlerinde hem de modern anlatı türlerinde yazar ve şairlerin yapıtlarında işledikleri arketipler/motifler/temalar 
olarak öne çıkmıştır. Yol ve yolculuk; özellikle anlatı kişilerinin dışa dönük seyahatleri ve kendi içlerine yaptıkları yolculuklar bağlamında masaldan romana, destandan öyküye birçok edebî türde işlenen temalardan olmuştur. Bu yönüyle değerlendirildiğinde yol ve yolculuk kavramlarının insanlık tarihinin temel meseleleri arasında yer ettiği söylenebilir. Tarihsel süreç içinde savaşlar, afetler ve kıtlıklar göçlere sebep olmuş; insanlar kendilerini güvende hissedebilecekleri bir yurt arayışına girişmişlerdir. Bu anlamda Türk destanlarında yol ve yolculuk değer olgular arasında yer almış, çeşitli sebeplerle bir mekânı terk edip başka bir mekâna kapı aralama veya ulaşma (erişme) kadim kültür geleneği içinde öne çıkmıştır. Aynı şekilde dinî hikâyelerde, efsanelerde, halk şiirlerinde ve mitolojik metinlerde de karşılaşlan yol ve yolculuk, bu tür edebiyat eserlerinin kimi yönlerden temasını oluşturmuştur. Geleneksel anlat1lar ve edebî türlerde olduğu gibi modern anlatılarda ve edebiyat türlerde de yol/yolculuk, sanatçıların eserlerinde işledikleri arketipler/motifler/temalar arasında yerini almıştır. Bu anlamda Orhan Pamuk'un Kara Kitap romanını yazarken geleneksel eserler olarak bilinen ve Doğu edebiyatının klasik anlatıları arasında gösterilen Hüsn ü Aşk ve Mantıku't-Tayr'daki serüvenlerle/yolculuklarla metinlerarası bir ilişki kurup bu anlatılardaki yol/yolculuk temasına değinmiş olması önemlidir (Moran 1997: 95).

\section{Yol ve Yolculuk}

Yol kavramı insanların, bir yerden başka bir yere gitmek üzere üzerinden ya da içinden geçtikleri, yerleşim merkezlerinin gelişimlerini doğrudan etkileyen, çeşitli düzen ve tasarılarla yaşamın önemli bir ögesini oluşturan mekânlar olarak tarif edilebilir. Mikhail Bakhtin romanda 'yol' kronotopunun işlevine değinirken anlatılarda karşılaşmaların genellikle yolda gerçekleştiğini belirterek yolun tesadüfi karşılaşmalar için özellikle iyi bir yer olduğunu belirtir. Bakhtin'e göre, "Yolda ('anayol') -tüm toplumsal sinıfların, zümrelerin, dinlerin, milliyetlerin, çağların temsilcileri olan- çok değişik insanların izledikleri uzamsal ve zamansal patikalar, tek bir uzamsal ve zamansal noktada kesişir." (2001: 317).

Yolculuk kavramı ise herhangi bir sebeple veya amaçla bir yere gitmeyi, bir şeyleri aramayı ya da bir şeylerden kaçmayı imleyen serüven ve edim olarak tanımlanabilir. Çoğu kez macera olarak da adlandırılan yolculuk, insanın dünya üzerindeki benlik ve kişilik sancısı olarak da değerlendirilmektedir. Tasavvufta "seyr u sülük" olarak adlandırılan yolculuk, geçici ve beşeri olandan hakikate ve mutlak varlığa geçişi simgeleyen manevi bir eylemdir (Cebecioğlu 2009: 565). Doğu kültüründe yolculuk, mistisizmden kaynaklı olarak manevi bir arayış olarak değerlendirilirken Batı kültüründe ise daha çok bir buluş, kaçış, yüzleşme ve geri dönüşü sembolize eder. İnsanlar bulma, görme, 
erişme, ulaşma gibi sebeplerle bilinmeyen, özlem duyulan, hayal edilen şeylere doğru bir yolculuk yaparlar. Bu husus kimi zaman bir mücadeleyi kimi zaman ise bir kaçışı içinde barındırır. Yalçınkaya da "Doğunun yolculuklarında yolculuğun temel sebebi arayıştır. Aramak aktif, beklemek pasiftir. Godot beklenir, simurg aranır. Hal bu olunca da arayış yolculuğun bir parçası hâline gelir. Çünkü klasik kültürün yolculuğu aktif bir arayıştır. Batınınki ise daha çok buluş, yüzleşme veya kaçmadır" (2007: 254) diyerek iki kültürdeki yol ve yolculukla ilgili yaklaşımların farklılığına işaret eder.

Bütün kültürlerde yol ve yolculuk insanın/bireyin dünyadaki kazanımlarını ve kişiliklerini çevreleyen, duyarlılıklarının ortaya çıkmasını sağlayan bir metafor olarak da düşünülebilir. Bireyin ontolojik kaygılları, kendi varlığının değeri ve bunun oluşum biçimleri gerçekleştirdiği yolculukların toplumsal yaşantılar ve mekânlarla kurduğu ilişkilerden doğan bir bütünlükle açıklanabilir. İnsan, üzerinde yaşadığı dünyanın içinde kaybolup gitmemek için sürekli bir devinim hâlindedir. İnsanın hayat içindeki mücadelesi ve kendini koruma isteği ruhunda ve zihninde beliren korku ve sanrılarla bütün benliğini kuşatır. Bu nedenle birey sürekli olarak bunalım ve sıkıntılarla boğuşur. Bunu aşmak ve feraha ermek için yolculuk düşüncesine ve yola çıkma isteğine kapılır. Bu yönüyle yol ve yolculuk, arayı̧̧ın sonunda insanın kurtuluş, erişme ve kendini gerçekleştirme arzusunu ifade eder. Eliade, zorlu bir süreci kapsayan yolu/ yolculuğu kutsal ve mutlak gerçekliğin bölgesi merkeze ulaşma olarak görür ve şöyle bir değerlendirmede bulunur:

Merkeze giden yol 'zorlu bir yoldur've bu gerçeklik düzeyinde doğrulanmaktadır. (...) Yol zahmetlidir, tehlikelerle doludur, çünkü dindışı olandan kutsal olana, geçici ve yanıltıcı olandan gerçeklik ve ebediyete, ölümden yaşama, insandan tanrıya geçiş ayinidir. Merkeze ulaşmak kutsallaşmaya, erginleşmeye [inisiyasyon] hak kazanmaya eşittir; dünün dindışı ve yanıltıcı varoluşunun yerini yeni bir varoluş, gerçek, kalıcı ve etkin olan yeni bir yaşam almaktadır (1994: 31).

Öte yandan yol ve yolculuk temasılla ilgili farklı teorik eserlere ve incelemelere de rastlamak mümkündür. Arketip (ilk örnek) kavramını psikolojiye kazandıran ve arketipsel eleştiri yöntemini temellendiren Carl Gustav Jung, 'aşama/yolculuk' arketipiyle çeşitli keşifleri, kurtuluşları, büyük arayış ve eylemleri tanımlar. $\mathrm{Bu}$ arketipe göre kahraman, bilinç dışını aşarak kişiliğini ortaya koymayı ve kendini gerçekleştirmeyi hedefler (Sambur 2005: 109). Jung'un "Yolculuk-Olgunlaşma/Aşama-Dönüş" biçiminde formüle ettiği kahramanın yolculuğu, aşama/yolculuk arketipinin gerçekleşme safhalarıdır. Yolculuk/aşama arketipinde maddi güçler/engeller aşılarak kimlik arayışı içindeki kahramanın yolculuğu bireyleşme ve bütünleşme ile sona erer. $\mathrm{Bu}$ bağlamda Jung, İnsan ve Sembolleri adlı eserinde ortaya koyduğu 'bireyleşme 
süreci' terimini bireyin bütünleştĭgi, kendi kendini gerçekleştirdiği ve tamlığa ulaştığ 1 bireysel bir tecrübe olarak tanımlamaktadır. Bu süreç, aşama/yolculuk arketipinin gerçekleşme şekli olarak görülür. Jung'a göre; "asıl bireyleşme süreci -kişinin kendi iç merkeziyle (ruhsal çekirdeğiyle) ya da selfiyle bilinçli olarak karşı karşıya gelme- genellikle kişiliğin yaralanması ve buna refakat eden acı ile olur. Bu başlatıcı şok, öyle algılanmasa da bir tür 'hidayet' şeklinde olur" (2007: 166). Jung'un 'bireyleşme süreci' olarak tarif ettiğgi bireysel deneyim bu yönüyle ruhsal yolculuğa benzetilir.

Teorik eserler arasında öne çıkan çalışmalarından bir diğeri ise Vladimir Propp'un Rus masalları üzerine yaptığı bir incelemedir. Masalın Biçimbilimi adını taşıyan çalışmasında Propp, masallarda kahramanların yolculuklar1 esnasında geçtikleri safhaları çeşitli başlıklar hâlinde anlatır. Masallarda "arayıcı kahraman" ve "kurban kahraman" olarak adlandırdığg iki tür kahramandan bahseder. Amacı bir şeyleri aramak/bulmak/getirmek olan "arayıcı kahraman"ın yola çıkma gereksinimlerini ve olasılıklarını anlatır (1985: 45). Joseph Campbell ise Kabramanın Sonsuz Yolculuğu adlı kitabında, kahramanın mitolojik serüvenindeki standart yolculuğunun geçiş ayinlerinde sunulan formülün geliştirilmiş bir hâli olduğunu belirtir. Kahramanın macerasını "ayr1lma-erginlenme-geri dönüş" şeklinde bölümlediği aşama/yolculuk arketipi etrafinda ele alır. Campbell'e göre; "Bir kahraman olağan dünyadan doğaüstü tuhaflıklar bölgesine doğru ilerler: burada masalsı güçlerle karşılaşır ve kesin bir zafer kazanılır: Kahraman, bu gizemli maceradan benzerleri üzerinde üstünlük sağlayan bir güçle döner" (2013: 42). Bütün bu hususlar çevresinde yol ve yolculuk temasının edebiyat eserlerinin temel bir motifi olduğu ve edebiyat biliminin de bu motifi incelemesi gerektiğini söylemek mümkündür.

\section{Nalan Barbarosoğlu ve Öykücülüğü}

Yol ve yolculuk teması çevresinde öykülerine yaklaşılacak olan Nalan Barbarosoğlu, Türk edebiyatında öykü türündeki ürünleriyle öne çıkmış yazarlardan birisidir. 1980'li yılların sonlarına doğru ilk öykü denemeleriyle okurun karşısına çıkan yazar, şimdiye değin Türkçeye kazandırdığg 6 öykü kitabıyla adını duyurmuştur. Barbarosoğlu'nun gerek kullandığı dil gerekse ele aldığ1 konular bakımından 1990 sonrası Türk öykücülüğünün özgün ve seçkin örneklerini verdiği söylenebilir. 1961'de Adapazarında doğan yazar, ilk ve ortaöğrenimini devlet okullarında tamamlamış; 1982'de İstanbul Üniversitesi Edebiyat Fakültesi Sistematik Felsefe ve Mantık Bölümünü bitirmiştir. Yazı hayatında metin yazarlığı, redaktörlük ve editörlük gibi görevler üstlenen Barbarosoğlu, yazı atölyesi çalışmalarında hâlen öğreticilik yapmaktadır. Yazar, edebiyat ve eleştiri dünyasına Yazko Felsefe'de yayımlanan Thomas Kuhn'un paradigma kavramını tartıştı̆̆ Bilimsel Devrimlerin Yapısı adlı ki- 
tabını tanıttığı yazısıyla adım atmıştır. Öykü yazmaya 1980'li yıllarda başlayan Barbarosoğlu'nun ilk öyküsü Argos dergisinde çıkmıştır. İlerleyen yıllarda öykü ve yazıları Yazko, Somut, Nar, Adam Öykü, E, Hece, Kitap-lık, Ü̧̧йncü Öyküler, Hece Öykü, Yom, Kassgar, Eşik Cini, Agora dergilerinde ve Radikal gazetesinde yer bulmuştur (Işık 2004: 308). Öykü türündeki ilk kitabı olan ve 11 öykünün yer aldığı Ne Kadar da Güzeldir Gitmek 1996'da Oğlak Yayınevi aracılı̆̆ıyla okurlarıyla buluşmuştur. Ardından sırasıyla Her Ses Bir Ezgi (Can Yayınları, 2001, 11 öykü), Ay Ģiçekleri (Can Yayınları, 2002, 13 öykü), Gümüş Gece (Alkım Yayınları, 2004, 11 öykü), Yol Işıları (Everest Yayınları, 2009, 14 öykü) ve Gümüş Gece (Alakarga Yayınları, 2015, 11 öykü) adlarını taşıyan öykü kitaplarını yayımlamıştır. Barbarosoğlu'nun öyküleri; “örgüsel sağlamlık, öz-biçim dengesi, estetik kayg1, ayrıntı düşkünlüğü, imgesel soyutlamalar açısından oldukça yetkin görün[mekte]" ve "tasvirciliğe düşmeksizin gerçekleştirdiği mekân belirlemelerinde de öyküsel gözle bakma ve nakletmenin yetkinliğini hissettir[mektedir]" (Lekesiz 2006: 204). Onun öykülerinin geneline bakıldığında ise "ağırlıklı olarak ölümlerin, ayrılıkların, terk edilmişliklerin ardından yalnızlığa gömülüp bütün acıları yaşayan kahramanların kendileriyle, hayatla yüzleşmelerini anlatır. Kahramanlar derin bir yanılg1 olarak yaşadıkları hayatın bir yerinde, acılı bir sarsıntıyla geçmişlerine döner; tüm bu yaşananlarla ödeşir; acıların, yalnızlıkların ve yanlışlıkların envanterini çıkarırlar” (Tosun 2015: 143).

Nalan Barbarosoğlu'nun öykücülük serüveninde kaleme aldığı öykülerin ve yayımlanan öykü kitaplarının geneline bakıldığında daha çok bireye odaklanan metinlerinde muhteva itibarıla kimi zaman yol ve yolculuk temasına yer verdiği görülmektedir. Özellikle yazarın ilk öykü kitabı Ne Kadar da Güzeldir Gitmek'te yer alan 11 öyküde yol, yolculuk ana izleklerden biri olarak öne çıkar. Bu kitapta yer alan öykülerdeki kahramanlar sürekli olarak bir kaçı̧ ve gitme arzusu içinde görünürler. Bir başka ifadeyle, Barbarosoğlu'nun kahramanları "burası olmayan bir yere" gitmek isterler. Dünyada ve gökyüzünde kendi olacaklar1 yeri aramaktadirlar (Tosun 2015: 145). Yazar, bu temalar çevresinde dönen öykülerinde bireyin yaşadığı dünyadan beklentilerini, hayatıyla ilgili hayallerini sıralarken arzuladığ̣ şeylere ulaşmayı, yol ve yolculuk imgeleriyle belirginleştirir. Ayrıca bu tür öykülerde, "Niçin, ne zaman ve nereye sorularının cevap bulmadığ bu hikâyelerde gitmek bir kaçı̧̧, kurtuluş ya da yeniden başlamak için bir firsat olarak görülür" (Uslu 2017: 362). Yazarın ilk kitabı Ne Kadar da Güzeldir Gitmek'ten Yol Işıkları'na uzanan süreçte kaleme aldığı öykülerde ise yol ve yolculukla ilgili tema, imge ve söylemler yok denecek kadar azdır. Bu öykülerde daha çok huzursuzluk ve mutsuzluk üzerinden bireyin içinde yaşadığı mekânla etkileşimine ve iletişim kurduğu çevresiyle ilişkilerine dikkat çekilir. Yol ve yolculuk teması, en belirgin hâliyle 
yazarın ilk öykü kitabından on üç yıl sonra yayımlanan Yol Işılkları kitabındaki öykülerinde kendini gösterir.

\section{Yolculuklara Adanan Hayatlar ve Dönüşsüz Yollar Bakımından Yol Işıłkları}

Yazıya konu olan Yol Işıkları, Nalan Barbarosoğlu'nun öykücülük serüveninde kaleme aldığı beşinci öykü kitabıdır. 14 öykünün yer aldığı kitapta sırasıyla "Gezgin, Kuzgun, Bilici”, "Ses-Fanus", "Yol Yorgunu”, "Kalp Ağrisı", "Tutuşan Temmuz", "Ateşten Bir Top", "Bisikletyaka Bir Kazak", "Adaya Gidemem", "Perdedeki Fisıltı", "Yol Eşiği”, "Mazeret İzni”, "Denize Gömülen Ada", "Mecnunu Yok Leylâ" ve "Gecikmiş Bir Veda" adlı öyküler bulunmaktadır. Kitapta yer alan öykülerin bir ikisi dışında Barbarosoğlu'nun yol ve yolculuk temasını işlediği , anlatılarda bu temalara ilişkin göndermelerde bulunduğu görülür. Necip Tosun, yazarın bu kitabında kaybedenlerin hikâyelerine ve lirik iç döküşlerine değindiğini söyler ve öykülerin '"gece', 'gitmek', 'kent', 'anne' kelime ve kavramlarını gündeme getirirken ağırlıklı olarak yol izleği etrafinda" döndüğünden bahseder (Tosun 2015: 147). Yazar, yol ve yolculuk teması etrafında öykülerinde karanlıktan aydınlığa, üzüntüden sevince, bunalımdan huzura kavuşmaya çalışan karamsar ve yalnızlığı benimsemiş bireyleri konu eder. Karakterlerin özellikle iç konuşmalarında yol/yolculuk bazen tematik düzlemi aşarak öykünün imgesel ve simgesel kodlarıyla bütünleşir. Yazar, bazı öykülerde yolu, yolculuğu ş̧ık imgesiyle bütünleştirerek arayış ve kaçış bağlamında bireyin sorunsalını ve çıkmazlarını daha etkili kılar. Ve bu 1şığın yol/yolculuk bakımından bir kurtuluşu imlemesini sağlar. İnsanın benliğini, ruhunu yansıtan bu öykülerde birey kabuğunun dışına çıkarak özüne ve kendi gerçeğine ulaşmaya çalışır. Bu doğrultuda yol ve yolculuk bir kaçı̧̧, kurtuluş, değişim ve dönüşümün habercisi olarak anlatılarda işlenir. Barbarosoğlu, "öykülerinde sıkça kullandığı yağmur, gece, karanlık, sanrı, kırgınlık, ayrilık, sakatlık, hastalık, yüzleşme, hesaplaşma, özeleştiri” (Lekesiz 2006: 203-204) gibi durumları çoğu kez gitme, uzaklaşma ve kaçı̧ gibi yola/yolculuğa dair eylemler üzerinden aktarır.

Yol Işılklar içinde yer alan öykülerin geneline bakıldığında birkaç öykü dışında ağırlıklı olarak "gitme", "yolculuğa çıkma", "dönüş", "kaçış" gibi edimlerin ağır bastığı görülür. Yazar, öykü kişilerini anlatırken onların içsel bunalımlarını, acıya evrilen hayatlarını ve yaşama dair endişelerini yol ve yolculuk metaforu içinde aktarır. Özellikle kırılmış, terk edilmiş, ihanete uğramış veyahut hayatın anlamsızlığına, acımasızlığına boyun eğen karakterler yol ve yolculuk teması etrafında anlatılır. Çoğu isimsiz daha doğru bir ifadeyle kimliksiz öykü kişileri gitme, yol, yolculuk ve kaçış arzusuyla içlerinde taşıdıkları bir umutla yaşarlar. ${ }^{\otimes} \mathrm{Bu}$ umut onları hayata bağlar, yeniden hayal kurmalarına 
olanak sağlar. Böylelikle öne çıkan öykü kişileri geçmiş ve şimdinin arasındaki onulmaz yaralardan sıyrılarak gelecekteki mutluluğu yakalamaya çalışırlar. Yol/yolculuk, gidişler ve dönüşler karakterler için yaşama tutunma biçimine dönüşür ve çoğu karakterin bu macerada sıkıntılarından az da olsa kurtuldukları görülür. Aynı zamanda öykülerde yer alan karakterlerin içinde bulundukları mekândan kendilerini soyutladıkları, az konuştukları ve sessizlik içinde günlerini geçirdikleri söylenebilir. Adler'in saldırgan olmayan tipler için ifade ettiği soyutlanmı̧ özelliğinin Barbarosoğlu'nun karakterleri için de geçerli olduğunu söylemek mümkündür. Zira yazarın öykü kişileri "kendileriyle başkaları arasına bir uzaklık koymaya çalı̧̧makla dikkati çekerler"(Adler 2017: 268). Bu sebeple öykü kahramanlarının soyutlanma ve uzaklaşma istekleri çoğu kez yol imgesi ve yolculuk arzusu bağlamında aktarılır. Kimi zaman da öykü kişilerinin iç konuşmalarında aktarılan zihinsel yolculuklarında kendi kişiliklerini gösterdikleri; birey olarak varoluşlarını sorgulayıp ortaya koydukları da söylenebilir. Bu varoluş mücadelesi içinde vuku bulan kaçışlar, hayaller, dönüşler de yol ve yolculuk ekseninde dikkate sunulur. Chatman'in "karakterler soyut olarak derin anlatı düzeyinde yer alan bir uzamda var olur ve hareket ederler" (2008: 129) düşüncesi de öyküde anlatılan kahramanların devinimlerini göstermesi açısından önemlidir. Çünkü çoğu öykü kişisi için hareket alanı bulduğu zaman/uzam (mekân) karakteri belirginleştiren, duygularını ve eylemlerini biçimlendiren bir özelliğe sahiptir.

Nalan Barbarosoğlu'nun öykülerinde karakterlerin kendilik sürecinde yol ve yolculuk daha çok başlangıcı ve yenilenmeyi imlemektedir. Bu yönüyle Barbarosoğlu öykülerinde yol ve yolculuk, kişiler için hem ayrıştırıcı hem de birleştirici nitelikleriyle ele alınır. Diğer taraftan ise kahramanların iç konuşmaları vasıtasıyla kendi içlerine yaptıkları içsel yolculuğu da sembolize eder. Bunun somutlaştırılması yani öykü karakterlerinin dışa dönük yolculukları da bir tür mutluluk, huzur ve güven arayışının ifadesi olur. Genel anlamda Yol Işılklar özelinde Barbarosoğlu öykülerinde somut ve sembolik anlamda gerçekleşen her yolculuk bir sınav veya sınama gibi kahramanları harekete geçirir. Öykülere yansıyan yol/yolculuk olgusu da ayrıllğın, gidiş ve dönüşlerin başlangıcını imgeler. Bu bağlamda Behçet Çelik'in kitap hakkındaki tespitlerini burada anmak yerinde olacaktır:

Karanlık bir yolda yürüyüp durduğumuzu hatırlatan öyküler yazıyor Nalan Barbarosoğlu. Kitabına Yol Işılkları adını koyması bundan belki de. Öykülerin ve öykü kişilerinin ruhlarına sinen karanlığı ikiye ayırmak mümkün: Bir yanda dışarısının karanlığı var; ailenin, devletin, rekabetçi sistemin ışık kaynaklarının önüne çektikleri setin hayatlarımıza düşen gölgesi. Öbür yanda içimizdeki karanlık dışarıdaki karanlığın içine doğduğumuz andan itibaren, korkularımızla, kaygılarımızla ço- 
ğalan, en yakın ve en sıcak duygularımızın önce 1şı̆̆ını soğuran, sonra onları da korkuya, kaygıya hizmet eden aygıtlara dönüştüren, kurumuş, kararmış, habisleşmiş iç dünyamızın 1ssızlığı1, 1şıksızlığı... (Çelik 2009).

\section{Yol ve Yolculuk Temasının Öykülere Yansıması}

Kitabın ilk öyküsü ve yazarının daha çok masal özelliği taşıdığını söylediği "Gezgin, Kuzgun, Bilici”nin giriş cümleleri baba evinden bir türlü çıkmaya cesaret edemeyen ve daima arzuladığı yolculukların hayalini kuran başkişi Gezgin'in hayatının masalımsı aktarımıyla başlar:

Gecelerden bir gece, dünyanın bilinmeyen bir yerinde ve vaktinde, bir gezginin iniltisi karışmış havaya, suya, toprağa. Babaevinin seslerini ve kokularını taşıyan bir iniltiymiş bu. Duyanlar anlamışlar ki, ruhu babaevine çakılı bir geçmekte hayattan... Ve ayağına sanki bir pranga takıll, gidememek fikriyle ağır $\mathrm{m}$ ağır. Binyıllar boyu düz edilmiş yollarda ne kadar giderse gitsin, taşıdığı ă̆ırlığı içinden söküp atamayanlardanmış aslında bu gezgin (Barbarosoğlu 2009: 1).

Öykü kişisi, yaşadığı muhitte evlerin çekilen perdelerini, kısılan ışıklarını fark edince bir başına kalmanın verdiği hüzünle kendi kendine hayıflanır. Hayalini kurduğu ama bir türlü gerçekleşmeyen yolculuklarının özlemiyle "kocaman dalgalı bir okyanusu" gözünün önünde canlandırır. Kendini "gökyüzünün alaca renklerini çalan dalgalara" bırakarak suyun içinde savrulduğunu hayal eder. Öyküde özellikle insanın aklı, vicdanı, hayatı arasındaki yolculuklardan ve bunların insan psikolojisine yansıması üzerinde durulmuştur. Öyküde metaforik bir adlandırma olan 'gezgin' modern bireyi simgeler. Gezginin fantastik yolculuğu, karşılaşmaları, geçmişinden bir türlü kopamayışı kabuğunu kıramayan insanı yansıtır. Bu yolculuk esnasında birey, kendine koyduğu sınırları ve aklın salt çizgileri arasında kalmış; hayat serüvenini tamamlayamamış bir nevi yarım kalmıştır. Anlatıcı, öykü kişisinin yolculuklardan korkusunu ve gidemeyişlerini şöyle ifade eder:

Gezginin tenini saran bir kabuk varmış meğer... Nefi bir kabuk... Teniyle kabuk arasında da babaevinin buğusuyla ağırlaşan annesinin nefesi; ve bu kabuğun kırılması bir yana çatlaması bile çok zormuş. Gezgin gittiği her yere ağır bedenini sürükleyerek taşırmış; dışardan ruhu olduğunu kabuk sayesinde güdük kalmış kanatlarının ruhunu bir türlü havalandıramadığını yükünden kurtulup hafiflemediğini kimseciklere anlatamazmı̧̧ (Barbarosoğlu 2009: 2).

Burada, gezginin düşleminden hareketle insanların kendilerine yarattıkları küçük dünyalarından söz edilebilir. Bu dünyalar karakterin ruhu, hayalleri ve düşlerinden arta kalan dış dünya ve iç evreninin yansımalarından ibarettir. 
Kişi bu mekânlar arasında sıkışıp kalmış; soyut anlamda bir yolculuk yapmaktadır. Bu anlamda Gezgin'in düşleri, bir yolculuk içinde anlam kazanır ve evrendeki varlığı yol imgesinin ruhunda belirmesiyle başlar. İç dünyasında kendine dahi itiraf edemediği şeyler zaman ilerledikçe birikir ve bu durum ruhsal anlamda gezgine ket vurur. Ağırlaşan yükün altında ezilen Gezgin, bu mahkûmiyetten yolculuk sayesinde kurtulabileceğini düşünmektedir. Ancak Gezgin, tıpkı diğer savrulmuş insanlar gibi yıllar boyunca nereye gittiğini bilmeden yürüyen ve asıl yolunu bulamamış bir kaybeden olarak anlatıyı sürükler.

Öyküde yolculuk esnasında karşısına çıkan 'Kuzgun' ve 'Bilici Kadın' onun yolculuğunu anlamlandıran ve ona yardım eden varlıklar/kişiler olarak belirirler. Bu varlıkları, Sarıçiçek'in kahramanın maceraya başlaması için doğaüstü güçlerden yardım alması, bu yardımın da ilahi varlıklardan gelebileceği gibi birtakım özel güçlere sahip insanlardan da gelebileceği yönündeki belirlemesiyle değerlendirmek olasıdır (2013: 87). Kuzgun, "dünyayı dolaşmaktan ve dolaşamadığını düşünmekten yorgun düşmüş” olup Gezgin'in hayal ettiği şeyleri yaşamaktadır. Bilici Kadın ise, Kuzgun'un yardımıyla Gezgin'i karanlıklar içinden alıp aydınlığa çıkaran ve yanlışlarını düzelten bir nevi kalbinin ve vicdanının sesi olarak öyküde konumlandırılmıştır. Bu yardımsever karakterleri, erginlenme sürecinde bir dizi sınavdan geçen kahramanı bu sınavlarda önerileri, tılsımları ve gizli araçlarıyla destekleyen doğaüstü yardımcılar, iyi kalpli güçler olarak görmek mümkündür (Campbell 2013: 113). Bilici Kadın'la sohbet eden Gezgin, karşısındaki görmüş-geçirmiş kadının sayesinde kendi olma süreciyle yüzleşir. Bilici Kadın, Gezgine "Bir yoldan geçiyorsun” diyerek tünelin sonunda karşılaşacağı bir çeşmeden bahseder ve buradaki bulacağı suyun kaderi olacağını söyler. Ardından Gezgin, Kuzgun'un da yardımıyla, onun pençesi ve kanatları altında bir yolculuğa başlar. Bu yolculuk esnasında yavaş yavaş kabuklarından sıyrılır ve her şeyden arınarak hafifler. Gezgin, Kuzgun'un pençesi altında yaptığı yolculukta gerçekte gözleri görmeyen Bilici Kadın’ın da yol göstericiliği sayesinde kendi gerçekliğine ve özüne ulaşır. Bilici Kadın ona artık kendi yoluna gitmesi/devam etmesi gerektiğini söylediğinde ise Gezgin'in aklına, "yola çıkmak" denildiğinde her yolun evden (babaevinden) başladığı düşüncesi gelir. Bu nedenle babaevi aklına düşer ve zihninde babaevinden son çıkışında eşik önünde, kolu evin kapısında sıkışıp kırılan babası canlanır. Babasını avutmak ve şefkatle kucaklamak istese de babasının aralarına koyduğu mesafe buna izin vermez (Barbarosoğlu 2009: 7). Masalımsı özellikler taşıyan ve öyküden daha çok bir masalı andıran anlatının sonunda Gezgin'in önündeki yolun üçe ayrıldığından bahsedilir: "Birinci yol, gitmenin keyfini çıkaran gezgin ruhlular içinmiş; ikinci yol, gitme cesaretini babaevine gömenler içinmiş; üçüncü yol 
ise nereye giderse gitsin yolu hep kendine çıkan, başkalarına açılmayanlar içinmiş" (Barbarosoğlu 2009: 7). Öyküde karşılıklı sorulan sorular, çıkılan sonsuz yolculukta birey(ler)in kendini ve kimliklerini kavrama sorunsalını ortaya koyar. Bilici Kadın ile Gezgin'in aralarında geçen diyaloglardan anlaşılacağı üzere anlatı kişilerinin dış dünyada yaptıkları yolculuklar, gerçekte iç dünyalarında başlayan bir yolculuğa evrilir. Yol ve yola çıkmak bir bakıma başkahramanın olgunlaşmasını/erginleşmesini ve sürecin sonunda da kendinin farkına varmasını sağlayan bir araca dönüşür.

"Ses-Fanus" öyküsü Edip Cansever'in "Çağrılmayan Yakup” şiirinde geçen "belli ki susmak yaratılmamış şekliydi dünyanın" epigrafiyla sunulur. Barbarosoğlu'nun bu öyküsünde anlattığı kahramanın adı da alıntıladığı şiirdeki gibi Yakup'tur. Yazar, bu öyküsünde âdeta Cansever'in şiirleştirdiği Yakup'u öyküleştirmiş; daima susan, çağrılmayan ve fark edilmeyen bireyi anlatmıştır. Öyküden anlaşıldı̆̆ kadarıyla kendini anlatacak/anlayacak birinin yaratılmış olmaması Yakup'un sessizliğinin asıl sebebidir. Öyküde başkişi arafta kalmışlık, sürükleniş ve belli belirsiz bir keşmekeş içinde sunulmaktadır. Zuhal'le tanışması onun hayatının dönüm noktası olsa da bir süre sonra onu terk edenler arasına sevdiği kadın Zuhal de katılır. Yakup, başlangıçta ruhunu sarmalayan fanus içinde kendisini anlayan tek kişinin Zuhal olacağını zanneder. Öyle ki Yakup, Zuhal'ı doğumu saymış onunla birlikte âdeta yeni bir hayata adım atmıştır. Sevdiği bütün şiirleri, bütün denizleri kısaca dünyaya dair her şeyi Zuhal'le daha çok sever Yakup. Yazdığı her kelimeyi Zuhal okuyacak diye cümlelerinin kanatlandığını anımsayarak yazar, o cümlelerle birlikte yüreği kanatlanır (Barbarosoğlu 2009: 11). Ama hayatının bir yalanını daha yaşamakta olduğunu ansızın terk edildiğinde anlar. Böylece Zuhal'ın kokusu da çevredeki kalabalığın kokusuna karışır. Öğrencilik günlerinde sıcak çay bahçelerinde başlayan sohbetler soğuk alışveriş merkezlerinin karanlık kafe duvarları arasında son bulur. Terk edilmenin ağırlığını yaşayan Yakup'un omuzlarına hayatın ağırlığı da eklenir. Bu duyumsamalar içinde göğsündeki ağrının hafiflediğini hisseden Yakup sokaklarda, caddelerde yürümeye başlar. Sıkça gittiği ve çıkmaz sokakta bir hanın giriş katında bulunan Amber Çay Ocağı'na ulaşır. Çay ocağına girmeden sokağın başında sımsıkı kapalı olan yedi kapıya rast gelir. Bu kapılar öykü kişisinin gitmekle kalmak arasındaki iç çekişlerini imleyen bir unsur olarak düşünülebilir. Zira bu kapıları karşısında gören Yakup bir an duraksar ve çay ocağına girmezden evvel bu kapıların hangi yolculuklara açılacağını düşünür. Mesleği yazarlık olan Yakup, kendisini kalemiyle var etse de varlığını yazının/yazmanın derinlikleri içinde yitirmiştir. Yakup, yazarken her şeyi çoğalttığını, çoğalttığı her şeyi de yitirdiğini çok sonraları anlayabilmiştir. Öykü kişisinin çay ocağına doğru yürüyüşü ve gelişi de yolculuk teması etrafinda bir tür kaçışı simgeler. 
Çünkü Yakup, ailesinden kalan tek kişi olan kız kardeşini bir maganda kurşunuyla kaybetmiş, onun "gencecik ölerek kendi kalabilmiş gerçeğini yitirmek istemediği” "için çay ocağına kaçmıştır (Barbarosoğlu 2009: 17). Ancak bu bir kaçıştan ziyade kardeşini ve onun ölümünü anımsatan bir acıya bürünmüştür. Burada yolculuk ve yol teması Yakup'un sevdiklerinden ayrılışı, kopuşu bağlamında alt tema düzleminde işlenmiştir. Yazar, kahramanını konuştururken çoğu kez yola/yolculuklara çıkarmakta ve bu yolculuklar esnasında onun hem geçmişini hem yaşadığı hayatı sorgulamaktadır. Bu yönüyle "Ses-Fanus" öyküsünde yol ve yolculuk teması, bireyin yalnızlığını, pişmanlığını, kaybedişlerini, üzüntüsünü ve en önemlisi kendini yitirişini yansıtması açısından öne çıkmaktadır.

Öykünün başında Nursel Duruel'in "Atlarını Sürüp Geldiler (Yol Yenisi)" öyküsünün verdiği esinle yazıldığı belirtilen "Yol Yorgunu” öyküsü de yol ve yolculuk teması etrafinda dönmektedir. Öykü kişisinin hiçbir istasyonda durmayan tren yolculuğuyla başlayan "Yol Yorgunu"nda, genç bir kadının hayatını sorgulamasını ve bir çıkış bulmaya çalışırken yolunu kaybetmesini anlatılır. Kadın kahraman; "Bu trene binmeden önce bir hayatım yokmuş gibi geliyor bana...” (Barbarosoğlu 2009: 21) diyerek tren yolculuğunu yeni bir hayatın başlangıcı olarak düşlemektedir. Bunalan, yaşadığı yeri yadırgayan, eylemsizliğe teslim olarak hayatın ağırlı̆̆ içinde yaşayan kadın karakter, bir bakıma bu yolculuğa tutunur. $\mathrm{Bu}$ yönüyle öykü kişisinin yolculuğa tutunmasını, hayata tutunma isteğiyle benzeştirmek olasıdır. Aynı zamanda genç kadın hayatla ilgili karmaşıklıktan trenin durmasıyla kurtulmayı yeğlemektedir: "Tren dursa, geçip giden görüntülerden kurtulsam, görüntüler ve sesler yerli yerine otursa ben de ağırlı̆̆ına kavuşurum belki, nesnelerden bir nesne, kuşlardan bir kuş, ağaçlardan bir ağaç, bulutlardan bir bulut, denizlerden bir deniz, insanlardan bir insan olurum" (Barbarosoğlu 2009: 22). Öyküde adı verilmeyen kadın karakter, bu düşünceler içinde bir süre sonra en iyi yapılacak işin 'uyumak' olduğunu düşünerek uykuya sığınır. Çünkü, kendisi uyuyunca dünyanın yerli yerine oturacağını düşünmektedir. Genç kadın, daldığı bu uykuda gördüğü rüya ile hayatı arasında bir özdeşlik kurar ve genç yaşta kaybettiği ağabeyini anımsar. Ağabeyinin de aralarında olduğu atllardan bahseder ve onun yolculuğa çıkışını "Abimin de aralarında olduğu atlılardan bir toz bulutu kalmıştı geride. Abimin bindiği doru atın akıtması alnımda kalmıştı, rüzgârı hırkamın içinde. Gitmişlerdi, atlarını sürüp gitmişlerdi” (Barbarosoğlu 2009: 23) şeklinde aktarır. Öykünün sonlarına doğru kadın karakter "Aylar geçiyor, mevsimler... Gidenlerin kimisi geliyor, kimisinden haber alınamıyor, kimisi dönmüyor... Kalanlar bekliyor... Gidenlerden hiç konuşulmuyor. Dönenler hiçbir şey anlatmıyor; kalanların arasına karışıp uzaklara bakıp bekliyorlar" (Barbarosoğlu 2009: 27) diyerek yol metaforu içinde ağabeyinin de aralarında 
bulunduğu yolculuğa girişen atlılarla ilgili olağan durumu özetler. Ardından ağabeyinin çıktığı yolculuktan dönmediğinden; annesinin omuzlarının çökmesinden ve babasının sürekli avluda oturmaktan dolayı yılkı atına benzediğinden söz açar. Öyküde genel itibarıla genç kadının ailesiyle ilişkisinden ve çok sevdiği ağabeyinin ölümünün ardından dağılan hayatından bahsedilerek yol ve yolculuk bağlamında arayışı somutlaştırılır. Tren, istasyon, gitme isteği, sonu gelmez yolculuklar ve bu yolculuklarda ailesini, geçmişini arayan/anımsayan genç kadının savrulan yaşamını okumak mümkündür. Aynı zamanda yolculuk teması doğum, yaşam ve ölüm üçlemesi çevresinde simgeleştirilerek 'kahramanın sonsuz yolculuğu'na da bir atıfta bulunulur. Genç kadının yalnızlıktan ve korkularından sıyrılma arzusu, annesini, babasını ve ağabeyini özlemesi bir bakıma bütün bu kaybedişlerin iç döküşü gibidir. Anneye, aileye dahası çocukluğuna sığınan genç kadın, yaptığı bu tren yolculuklarında sürekli bir şeylerden kaçmaktadır. Ancak, sonunda öykü kişisi derin bir hayal kırıklığ1 yaşar ve bu hayal kırıklığını yolculuk yaptığ1 trenlerle ilgili söylediği "Nerden bilirdim bitmeyen yollardan gelip bitmeyen yollara gittiğini ve hiçbir istasyonda durmadığını, yolcularını bir türlü bırakmadığını... Herkese meşrebine göre ömür biçen bu trenden atlamaya çalı̧sanları da gördüm" (Barbarosoğlu 2009: 28-29) cümleleriyle dile getirir. Barbarosoğlu, öyküde herkesin bir yolu olduğu ve bu yolda yürüdüğü anlatılırken tren, istasyon ve yol imgesi etrafinda modern insanın/bireyin iç muhasebesini yapar. Genç kadın tren durduğunda uğultuların toprağa karışıp havaya dağılmasıyla kendisinin de seslerin, renklerin ve kokuların yerli yerine oturduğu bir sessizliğin içine çekilebileceğini tasavvur eder. Bütün yorgunluğunun toprağa akacağını ve böylece hiç yaşamamış gibi sonsuzluğa karışacağını düşler.

Kahraman anlatıcının çevresinde dönen "Kalp Ağrısı" öyküsünde de yol ve yolculuk temasına az da olsa rastlanır. Adı verilmeyen erkek öykü kişisi kendi hikâyesini aktarırken annesinin hayatından kesitler sunar ve babasının annesini aldatıp terk ettiğginden bahseder. Öykünün ana örgüsünü/çerçevesini, annenin ihanete uğraması üzerine yaşadığı buhranla birlikte bir çocuğun (oğulun) gözleri önünde annesinin erimesine/ölmesine tanıklık etmesi ve onun psikolojisiyle hayatına devam etmek zorunda kalışı oluşturur. Öykünün anlatıcısı konumundaki başkahramanın sevdiği biri vardır ve bu kişiyle aralarında kalın bir duvar örülüdür. Bu iletişimsizlik hâli onu sessizliğe iter ve kahraman çoğu kez kendi kendisiyle konuşurken görünür. Sevdiği kadından ve sevdiği şehirden ayrılacağını/uzaklaşacağını; "Bir şehirden onu bir daha görmeyeceğini bilerek ayrılmak. Şehirde şehri gören gözleri bırakmak... (...) Şehrin seni beklemeyeceğini bilerek gitmek" (Barbarosoğlu 2009: 31) cümleleriyle ifade eder. Yaşadığı şehirde gün doğumundan gün batımına hayatına karışan her şeyi bırakıp gitmek isteyen erkek karakter, gurbeti kuşanarak giden ve 
şehrin koynunda doğan insanı şehrin bekleyip beklemeyeceğini de sorgular. Bir bakıma, "Tüm bu olumsuzluklarda kahraman için gitmek bir çıkış yolu olarak gözükür” (Tosun 2015: 148). Böylece adı geçen öyküde gitmek, unutmak, özlem, dönmek, yolculuk, gurbet ve şehir kavramları etrafında yaşamın getirdiklerinin bir sorgusu yapilir.

Yol/yolculuk teması etrafında dönen kitabın beşinci öyküsü "Tutuşan Temmuz" ise ben anlatıcı konumundaki öykü karakterinin yaptığı uzun bir yolculuğun anlatımıyla başlar:

Güzün ilk günlerinde bir ikindi vakti, kadim zamanlardan kalma taş bir yoldayım ki, kocaman gövdelerine ve kocaman seslerine hiç yakışmayan hüzünlü gözleriyle köpekler önüme çıkınca, anlatılan âşıklar yöresine, o büyük ırmağın doğduğu topraklara geldiğimi anladım. Köpekler önde, ben arkada pencerelerinden, kara üzüm çardaklı avlularından bağlama seslerinin taştığı, âş̧ıların bahçeden bahçeye atıştığı evlerin önünden geçtik... (Barbarosoğlu 2009: 41).

Adı verilmeyen öykü kişisinin aktardığı bu cümleler, ileride öyküde anlatılacaklarla ilgili bir ipucu niteliğindedir. Büyük şehirden -belki İstanbul- kalkıp gelen öykü kişisinin Anadolu şehrinde/köylerinde -daha sonra Sivas olduğu anlaşılan- yapılacak olan şenlikleri görmek için bu yolculuğa çıktığı anlaşılır. Kahramanın uzun yolculuğunun ardından içlerine dâhil olduğu insanlarla münasebeti, Anadolu köyünde karşılaştı̆̆ı hususlar, dinlediği öyküler ve geçmişe dair anlatılan acıklı yaşam deneyimleri öykünün genel çerçevesini oluşturur. Ben anlatıcı köye vardığında yolculukla ilgili gözlemlerini mekân ve insan etkileşimi içinde dile getirir. Bozuk ve susuz çeşmeler, kesik kesik havlayan köpekler, hasatta çalışan köylüler, meraklı ve sorgulayan bakışlar, ırmak, dağ, köy meydanı ve şenlikler üzerinden izlenimlerini aktarır. Öykünün sonunda ise şenlikleri izleyen ve köylülerin anlattığı acıklı yangın hadisesini dinleyen öykü kişisi, köyde kendisine kılavuzluk eden Seyfi'ye artık burada kalamayacağını belirtir. Öykü kişisi "yolcu yolunda gerek, geceyi taşıyan toprakta uyumaya alışkın bu gövdedeki yürek, bir ağaç gövdesi istiyor” (Barbarosoğlu 2009: 53) diyerek yola koyulur. Şehirlerarası yapılan bir yolculuğun anlatımı olan öykü, ben/kahraman anlatıcının "Seyfi'nin aydınlık alnından öptüm, verdiği kemik saplı bıçağı heybeme koydum... Yıldızları parlak gökyüzüne baktım ve yürüdüm... Beni binyıllardır kocaman dalgalarında biriktirdiği hikâyeleri uçsuz bucaksız kıyılarına bırakan denize götürecek o büyük ırmağa doğru yürüdüm” (Barbarosoğlu 2009: 54) şeklindeki yol/yolculuk imgesiyle yüklü cümlelerle son bulur. Bu öyküde Anadolu'nun uzak şehirlerinden birine yapılan seyahatte öykü kişisinin gördüklerinden, dinlediği hikâyelerden arta kalan acı ve hüzün dikkatlere sunulur. Öykü kahramanı, gözlemlediği ve 
dinlediği şeylerden kaynaklanan huzursuzluğu bulunduğu ortamı terk ederek -bir tür yolculuğa çıkarak- azaltmaya çalışmıştır. Şehri sarmalayan kederli hatıraların izlerini benliğinden ancak böyle silebileceğini düşünmüştür.

"Ateşten Bir Top" öyküsü ise Türkiye'nin siyasal ve sosyolojik tarihinde topluma dönük sorunların bireyin hayatına ne ölçüde yansıdığıyla ilgilidir. Öyküde yol ve yolculuk, alt tema olarak işlenmektedir. Ben anlatıcı tarafindan "ateşten bir top"a dönüştüğü, yaşanmaz kılındığı imlenen Anadolu coğrafyasında insanların yöneten sınıfın yanlış planlamalarından dolayı oturdukları evlerden, yaşadıkları yerlerden gitmek zorunda kalmalarını ve çaresizliklerini dikkatlere sunar. Ben anlatıcının arkadaşıyla yaptığı hayali diyaloglar çevresinde evleri baraj suları altında kalan ve askeri idarenin insafinda yaşayan köylülerin yitirdikleri geçmişten ve yaşanmışlıklardan bahsedilir. Kimsesizliği ve çaresizliği olabildiğince yaşayan köylüler, bağları ve bahçeleri sular altında kalınca hayvanlarını yok pahasına satıp köylerini terk ederler. Dönüşsüz bir gurbet yolculuğuna atılanlar, geride, toprağa benzemeyen bir toprak, gece taşa dönüşen yıldızlar, bir suç ortağına dönüşen rüzgâr ve yangınlara yağmuru esirgeyen bulutlar bırakırlar. Bu hayali konuşmada ben anlatıcı kahraman çaresiz kalınca arkadaşı Civan’ öldürür ve o da diğerleri gibi bir günahın çevrelediği kişi hüviyetine bürünür (Barbarosoğlu 2009: 64). Denilebilir ki öyküde yol ve yolculuk teması; zorunlu göçü, çaresizliği, merkezi otorite eleştirisini ve iletişimsizliği çevreleyen bir dikkatle işlenmiştir.

Kitabın belki de en sıcak öykülerinden olan "Bisikletyaka Bir Kazak"ta ben anlatıcının ağzından yaptığı yolculuğun akabinde misafir olduğu evde gördügü bir düş anlatılır. Öykü, kadın kahramanın bir yolculuğun bitimine denk gelen "Geldiğim şehrin dış mahallelerinde konuk edildiğim evde göğsüme bastırdığım bisikletyaka bir kazağın sıcaklığında uyanıyorum” (Barbarosoğlu 2009: 65) cümlesiyle başlar. Düşünde yatılı okulda öğrenim gören oğluna bisiklet yaka kazak ören bir annenin geçmişi, kocası ve aile hayatıyla ilgili olumlu ve olumsuz durumlardan bahsedilir. Ben anlatıcının düşünde gördüğü anne de tıpkı kahraman anlatıcı gibi öğretmendir ve bu nedenle rüyası kendi yaşamının küçük bir kesitini içerir. Bu anne-öğretmen diğer öğretmenlerden ayrı olarak kendisi gibi öğretmen olan kocasının çokbilmişliği ve bir türlü peşini bırakmayan gölgesi altında ezildiğini düşünmektedir. Bu sebeple annede/öğretmende daima bir eksiklik, kendi olamama, kendini ifade edememe ve kendini gerçekleştirememe sorunları belirir. Kocasının gölgesinde ve her şeyi bilen tavırları arasında süre giden hayatını sorgular. Bu sorgulamalar içinde ebeveyn olarak çocuklarına yaklaşımlarını da gözden geçirir. Örmekte olduğu bordo rengindeki bisiklet yaka kazak aslında onun bütün dünyaya içini dökmesine olanak sağlar. Öğretmen anne, çevresi -bilhassa kocası- 
tarafından kabul edilmemişliğin verdiği psikolojiyle eşine, iş arkadaşlarına kırılır. Öğretmen anne bu psikoloji içinde bunalımlı günlerinde ördüğü bisiklet yaka kazakta teselli bulur. Kazağa verdiği emek ve yüklediği anlamlarla dertleşip kendini anlatmaya çabalar. Oğluna bisiklet yaka kazak ören anne, kazağın üzerine işlediği dört hayat ağacından ilkine geçmişini, ikincisine bilgisizliğini, üçüncüsüne sevgisine karışan sezgisini ve dördüncüsüne de burnunu sızlatan özlemi koyar. Annenin hayat ağaçları içinde kendi hanesine yazdığ1 ve kendi payına düşen olarak gördüğü özlem duygusunun içinde bir hayat isteği belirir. Bu hayatla ilgili arzusunu oğlunun da isteyip istemeyeceğini düşünür. Yazar, öykünün sonlarına doğru annenin iç konuşmaları çevresinde kuş ve göç imgeleriyle yol/yolculuk temasına değinir: "Dördüncü hayat ağacının üstüne de bir kuş kanadı konduruyor anne... Kırlangıç olabilir mi?.. Belki... 'Göç eden bir kuş işte,' diye mırıldanıyor. Ruhundaki göçmen kuşlar havalanıyor sanki... Leylekler, ördekler, kırlangıçlar, turnalar..." (Barbarosoğlu 2009: 71).

“Adaya Gidemem” öyküsü adıyla özdeşleşen bir gitme ve yolculuk isteğinin dışavurumu olarak okurla buluşur. Öyküde, Ekim ayında bir deniz şehrinde -muhtemelen İstanbul- bulunduğunu ve içinden dışına, dışından içine gitme zamanının geldiğini söyleyen ben anlatıcının hayatına dair kesitler sunulur. "İnsan hayatın kör noktalarından da kendine gitmeli belki. Alabildiğine kendine doğru yol almalı” (Barbarosoğlu 2009: 73). Öykünün anlatıcısı konumundaki kadın karakterin anlattıklarından genç yaşta eşini kaybettiği ve bir bebek beklediği anlaşılır. Öyküde aynı zamanda Sait Faik'in "Hişt Hişt" öyküsüne göndermeler yapılmış, ben anlatıcının ada ve deniz şehrindeki hayatı ve hayatına bir mektupla giren "hişt hişt" sesi Sait Faik'in yazın yaşamı ve öyküleriyle benzeştirilerek/özdeşleştirilerek aktarılmışır. Karnında bebeğiyle dul kalan kadın, uzun zamandır "Bir Nisan sabahı, posta kutu[suna] bırakılan bir mektuptan çıkıp hayatına yerleşen adaya gidebilecek miyim” (Barbarosoğlu 2009: 74) sorusuyla meşgul olur. Gitmeyi gerçekten isteyip istemediğini sorgular. Bu sorular içinde Sait Faik'in hayatına ve öykülerine tutunur. Yazarın Adalar ve İstanbul yaşantısından, öykü yazma macerasıyla ilgili hususlardan kendisiyle ilgili ortak paydalar bulmaya çalışır. Genç kadın, geçmişindeki olumsuzluklardan dolayı adada kendisine yönelecek çatık kaşlı bakışlardan, önüne dikilecek yargilardan korkar. Bu korkusu sebebiyle yolculuk bir türlü gerçekleşmez. Farklı ve alış1lagelen kalıpların dışında bir hayata adım atmaya hazır olduğunu söylese de, dul bir kadın olarak yaşamanın zorluklarını benliğinde hisseder. Bu düşüncelerden kurtulma adına sık sık Sait Faik'in yazı odasına, öykülerine ve yazarken hissettiklerine sığınır. Buruşan ipekli mendiller, kırılan aynalar, kararmış semaverler, can çekişen 
dülger balı̆ğ ve anlamı olmayan denizin rengi karşısında kendisiyle konuşmayan bir dünyanın varlı̆̆ından yakınır. Öykü, kahraman anlatıcının "Evet, adaya gidemem. Bunu ben belki -ben de sarı bir bakkal defteri alıp o yazarı taklit ederek çakıyla yontulmuş sabit bir kalemle- yazmalıyım. Sayfalar dolusu: Adaya gidemem! Adaya gidemem! Adaya gidemem!...” (Barbarosoğlu 2009: 84) şeklindeki yine bir gidememe ve Sait Faik göndermeleri barındıran cümleleriyle son bulur.

Bir kapı sesi imgesiyle başlayan "Perdedeki Fısıltı" öyküsünde ise askeri personel olduğu anlaşılan genç bir adamın hayatı anlatılır. Kapısı imgesi gidiş ve dönüş ikileminde öykünün yola/yolculuğa dair olduğunu; yazarın da kap1 sembolüyle 'içeri'yi ve 'dışarı'yı işaret eden soyut bir uzama gönderme yaptığ 1 düşünülebilir. Üçüncü tekil şahsın ağzından aktarılan öyküde, öykü kahramanının yaşamıyla ilgili durumlar paragrafların başında sürekli tekrar edilen "Gittin işte... Gittin" söz öbeği çevresinde sunulur. İsimsiz kahraman anlatıcının, başka bir şehre tayin olan ve yolculuğa çıkan askeri personel arkadaşı için sarf ettiği "Gittin işte... Gittin. Oraya. Harita paftasında işaret parmağ1nın ucuyla kapanabilen yere. Yola görev mehil izninin bitmesine üç gün kala çıktın. (...) arkandan bakan yoktu, su döken de. Yolun açık açık olsun diyen ya da tez gel diye fisıldayan bir ses duyulmadı arkandan” (Barbarosoğlu 2009: 87) cümleleri öykünün yol ve yolculuk teması etrafinda kurgulandığını gösterir. Bu cümleler öykünün anlatıcısı konumundaki kişinin öykü kahramanın yakın bir erkek arkadaşı, dostu veya sevgilisi olabileceğini düşündürür. Öykünün sonuna değin de anlatıcının kim olduğu belirsizliğini korumaktadır. "Gitme" eylemi üzerine kurulan öyküde karakterin hayatına dair kesitler düşler, yolculuklar, hatıralar, hayaller ve pişmanlıklar etrafinda okura aktarılır. Öykü, başkişi askeri personelin geçmişiyle yüzleşmesi, hatıraları, kimsesizliği ve artık kanıksamış olduğu yalnızlığı gidişlerinin yorumlanmasıyla anlatılır. Yolculuklarının birinde öykü kişisi arkadaşı Erkan'ın düğünde görülür. Dügün sahnesinde bu belirsiz anlatıcı kahramanın erkek olduğunu anlar okur. Anlatıcı kahraman, düğünde kimi zaman bir rüya içinde kaybolur ve hayata dair çeşitli yorumlar yapar. Bir keresinde yıllar öncesinden ev arkadaşının hazırladığı bavulları ve ona nereye gittiğini sorusunu yönelttiğini anımsar. Kahraman anlatıc1, arkadaşını 1ssız koylarda, gecenin koyu vakitlerinde, bozkır ayazının çöktüğü küçük şehirlerde görünce/bulunca terk edilmişliğin içinde bir acıyı tamamlıyormuş gibi hissettiğini itiraf eder. Asker olan arkadaşının yeni görev yeri olan küçük şehre ayak bastığında göç vermekten büyüyememiş ve kendinden kurtulamamış bir şehirle karşılaştığını fark ettiğini belirtir. Kahraman anlatıcının öykü başkişisinin mesleğiyle ilgili hususları aktarırken yer yer geçen zamana dair hatıralarına göndermede bulunur. Bu hatıralarını 
yola ve yolculuğa eklemlenen gitmek, kalmak, şehir, bavul, yalnızlık imgeleri ve kavramları içinde dile getirir. Chatman'ın deyişiyle öyküdeki zaman/uzam bir bakıma "karakteri belirginleştirir; karakterler de eylemlerini ve duygularını, nesnelerin toplandığ1 yer olan zaman/uzama 'karşı' uygun bir biçimde ortaya çıkartılar” (2008: 130). Öykünün finalinde başkahramanın ağzından kaldığı misafirhanede bütün gidişlerinin sentezi yolculuk arzusu üzerinden aktarilır:

Hayatımın bir omurgası yok. Yumuşakçalar gibi yavaş ve şuursuz bir devinim içinde soluk alıp veriyor gibiyim. Yaşadığım her şey dağınık. $\mathrm{Bu}$ dağınıklıkta ben de dağılıyorum. Bacağım, ayağım başka yerde, kolum, elim bambaşka yerde sanki. Ucunu kaçırdığım bir parçalanmanın titrek sinyalleri gövdemle başım arasında. Her geçtiğim sokakta başka biri mi oluyorum ne? Her girdiğim evde başka bir yüzümle yüzleşiyorum. Değişmeyen tek şey aynadaki görüntüm. $O$ görüntüye her defasında başka bir nitelik yüklüyor gözlerim. Gitmem lazım... (Barbarosoğlu 2009: 98-99).

"Yol Eşiği" adlı öyküde Ceyda ve Cemal adında iki öğretmen çiftin hayat serüveninden ve ayrılmalarından bahsedilmektedir. Öykü dönüşümlü olarak iki kahramanın ağzından anlatılmakta olup yaşadıkları, evlilikleri, ayrılıkları ve öğretmenlik günleri iki karakterin bakış açısı çevresinde verilmektedir. Öykü kişileri duygularını ifade ederken ayrılıktan, gitmekten, yolculuktan ve dönmekten sıkça söz ederler. Öykünün girişinde okur, başkahraman Cemal'in "Şimdi siz beni böyle gecenin geç bir vaktinde, elinde kocaman bir sirt çantasıyla, aralık duran ve girişinde lamba yanan sokak kapısının önünde görünce bir yolculuğa çıktığımı düşüneceksiniz" (Barbarosoğlu 2009: 100) şeklindeki yolculuk imgesiyle bezenmiş cümlesiyle karşılaşır. Cemal, eşikte sanki birini bekliyormuş gibi tedirgin, bir şey unutmuş ve unuttuğunu anımsamaya çalı̧̧anlar gibi kararsız bir hâldedir. Cemal'in anlattığı nesnelerden hareketle onun evden ayrıldığı ve bir yolculuğa çıkmaya hazırlandığı anlaşılmaktadır. Anahtar, kapı, portmanto, bere ve otobüs nesneleri/eşyaları kahramanın adını andığı; bir yolu, yolculuğu imleyen şeylerdir. Cemal bu eşyalar ve nesneler içinde "şimdi yola koyulma vakti" diyerek evinden ayrılır ve ardından da "bir başka hayata yol aldığı"nı dile getirerek otobüse yetişmeye çalıştı̆̆ını anlatır. Cemal, "İnsan ayağını eşikten dönmek üzere atıyorsa, otobüsü kaçırdım diye geri gelmesi pek yakışık kalmaz. Evet, dönmemek üzere gidiyorum” (Barbarosoğlu, 2009 102) şeklinde söylenir. Böylece asıl terk edenin kendisi olmadığını; terk edildiği için gitmeyi göze aldığını ifade eder. Olayın gerçekliğini de içerdekinin yani eşi Ceyda'nın anlatmasını ister. Bu söylemlerden sonra sözü diğer öykü kişisi Ceyda alır ve öykü onun ağzından aktarılır. Ceyda ko- 
casının gitmemek ve kendisini terk etmemek için epey bir süre direndiğini, öğretmenlik yaptığı ücra kentte gidenlerin gelenlerden çok daha fazla odluğunu söyler. Cemal'in de sonunda diğerleri gibi gidenler kervanına katıldı̆̆ını belirtir. Ceyda'nın iç konuşmalarından yıllardır yola çıkmak şöyle dursun yola çıkmayı bile hiç düşünmediği anlaşılır. Ceyda'nın anlatımıyla Cemal'in eşini ve işini neden bıraktığını bütün sebepleriyle öğrenir okur. Son kertede sözü yine Cemal alır ve yolculuğa çıkışını geliş macerasına benzeterek şöyle anlatir:

Yedi yıl önce böyle otobüslerden biriyle gelmiştim buraya yukarıdaki şehirden. Gidişim de farklı olmuyor. Gitmek böyle mi olmalı?.. Vedalaşmadan, içimdeki ikircikliği ve çaresizliği dile getirmeden, hepsini bırakın, Ceyda’yı şöyle sıkı sıkı bastırıp göğsüme, sarılmadan gidebileceğim hiç aklıma gelmezdi doğrusu. (...) Ben de hiç mi hiç yakıştıramıyorum kendime. Kime yakışır ki, böyle gitmek... (Barbarosoğlu 2009: 111).

Yazar, otobüsle yolculuğa çıkan Cemal'in iç konuşmalarıyla öyküyü sonlandırırken iyiden iyiye yalnızlaşan öykü kişisinin nereye gitse oraya ait olamadığını, sanki gitmediği/görmediği yerlerin insanı olma eğilimi içinde olduğunu okura gösterir. Ve bu husus anlatıda, kaderin çevrelediği bir olgu gibi sunulur. "İçinize doğru yol aldıkça, özellikle başlarda, dışınızdakilerle aranızdaki mesafe genişliyor” (Barbarosoğlu 2009: 113) cümlesi de öykünün yol ve gitmekle ilgisini örnekleyen bir başka ifade olarak dikkati çeker. Burada Campbell'in deyişiyle kahramanlar için "alışılmış yaşam ufku genişlemiştir; eski kavramlar, idealler ve duygusal kalıplar artık yetmez; bir eşiği aşma zamanı gelmiştir” (2013: 66). Bu öyküde yol/yolculuk teması anlaşamayan evli çiftin birbirlerinden uzaklaşması üzerinden okura sunulmuştur. Konuşamayan karakterler iç monolog ve bilinç akışı teknikleriyle ayrılıklarının, gidişlerinin ve yolculuklarının sebeplerini kendilerince ortaya koyarlar. Belki de yazar, birbirinden kopma noktasına gelmiş evli çiftleri iç monolog tekniğiyle konuşturarak iç sesleriyle hesaplaşmalarını ve öteki/karşısındaki benin karşıtlığını kabul ettirerek onları bilinçli bir sayıklamanın içine sokma niyetindedir (Kolcu 2015: 40).

Kitabın son dört öyküsü; "Mazeret İzni” "Denize Gömülen Ada”, "Mecnunu Yok Leyla" ve "Gecikmiş Bir Veda"da ise yol ve yolculukla temasıla ilgili doğrudan bir aktarım ve değini yoktur. Bu öykülerde gitmek, dönmek ve kalmak eylemleri yol ve yolculuk temasından daha çok öykü kişilerinin psikolojik tutumları ve gerçekleşmesini istedikleri ama bir türlü gerçekleşmeyen şeylerden hareketle verilmiştir. Yola/yolculuğa dair tematik düzlemde bir değini olmamakla birlikte diğer öykülerde fazlasıyla görülen gitme, kaçma ve 
sığınma isteklerinin bu üç öyküde sezgisel bir şekilde verildiği söylenebilir. Özellikle ben (kahraman) anlatıcıların iç konuşmaları çevresinde verilen ve hayat karşısında kendini konumlandırmada zorluk çeken, mutsuz karakterlerin içlerinde sürekli devinen bir başka şehre, bir başka eve, bir başka dünyaya gitme (ölüm/intihar) isteklerini bu bağlamda düşünmek olasıdır.

\section{Sonuç}

Öykülerinde daha çok imgesel bir anlatım tercih eden ve örtük anlamlarla bütünleşen öyküler yazan Nalan Barbarosoğlu, Yol Işılkları kitabında da aynı yöntemi izlemiştir. 14 öyküden oluşan eserde 10 öykünün doğrudan veya dolaylı olarak yol ve yolculuk teması etrafinda yazıldığını söylemek mümkündür. "Gezgin, Kuzgun, Bilici", "Ses-Fanus", "Yol Yorgunu" ve "Yol Eşiği”" öykülerinde doğrudan bu temaya temas eden yazar, "Kalp Ağrısı", “Tutuşan Temmuz", "Ateşten Bir Top", "Bisikletyaka Bir Kazak", "Adaya Gidemem”, "Perdedeki Fısıltı" gibi öykülerinde ise ana temalarla bağdaştırarak alt/yan tema bağlamında yol ve yolculuk temalarına yer vermiştir. Yola/yolculuğa yer vermediği dört öyküsü "Mazeret İzni", "Denize Gömülen Ada”, "Mecnunu Yok Leylâ" ve "Gecikmiş Bir Veda" ise bu temaların karakterlerin iç konuşmalarında bir imgelemem olarak sezdirildiğini söylemek mümkündür. Barbarosoğlu Yol Işı ılari'nda yol ve yolculuk temasını öykü karakterleri bir çıkış, kaçış, kurtuluş umudu olarak işlemiş; her yolculuğun insanı sonunda mutluluğa, huzura götüreceği yanılsamasını iç monolog ve bilinç akışı teknikleri vasıtasıyla aktarmıştır. Öykülerde sürekli hayali kurulan yola çıkma hevesleri ve gerçekleştirilen yolculuklar kimi zaman amacına ulaşamasa da hayatın kıyısında çırpınıp duran karakterler için kurtuluş umudu olarak görülmüştür. Bazı öykülerde ise kişilerin hayali olarak yaptıkları içe dönük yolculuklar da, sürekli olumsuzlukların çevrelerinde kol gezdiği kahramanların kendi gerçekliğinden sıyrılma ve yaşanan hayatın bir anlık dışına çıkma arzusu olarak ele alınmıştır. Bununla birlikte öykülerdeki karakterlerin yolculuk esnasındaki çıkış ve değer arayışlarına varoluşsal kaygılar da eşlik etmektedir. Bu bakımdan bireysel bir perspektiften aktarılan yol ve yolculuk olgusu yeni değerlere ulaşmada ve mutluluğa erişmede kahramanlar için içsel bir yolculuğun ilk adımını oluşturmaktadır. Öykülerde "hiçbir zaman kendi olamamış, hayata bir şekilde yenilmiş, kıyıya vurmuş kahramanlar, varla yok arası kişiliklerinden kurtulmak, yeni bir kimlikte, yeni bir sabaha uyanmak isterler" (Tosun 2015: 143). Öykü kişilerinin yaşamlarını anlamlandırma çabaları çoğunlukla gitme ve yolculuk isteğiyle dişa vurulur. Kahramanlar; gidişleriyle mutluluğa erişmeye, huzura kavuşmaya, yalnızlıklarını yenmeye, kötülüklerden korumaya, seslerini bulmaya ve hayata tutunmaya çalı̧ırlar. Alacakları veya 
yürüdükleri yol bir bakıma onlar için sessiz bir çığığa dönüşür. Bu bakımdan yol ve yolculuk teması, içlerinden başka gidecek yerleri olmayan karakterlerin yitirdikleri güzellikleri tekrar yakalayabilmeleri ve gidenleri geri getirmeleri adına bir umut ve düş olarak öykülerde işlenmiştir.

Sonuç olarak Yol Işılkları, Nalan Barbarosoğlu'nun farklı temaları içeren bir eseri olmakla birlikte yol ve yolculuk izleğini karakterlerin yaşantıları ve psikolojik durumları çevresinde sunması açısından önemlidir. Diğer taraftan anlatıların genelinde öykü kişilerinin hayata, ölüme, yaşama, unutmaya, özleme, tutunmaya kısacası iyi insan olmanın ve bu iyiliği bütün insanlığa yaymanın kaygısını taşıdıkları görülür. Bu yönüyle yol ve yolculuk teması karakterlerin mutluluğa, huzura kavuşma endişelerini; kendilerine yapılan haksızlıkları ve kötülükleri unutarak karanlıktan aydınlığa çıkabilecek yeni bir hayat kurabilme hayallerini de ihtiva etmektedir. Öykülerden anlaşıldığı gibi acı çeken, sessizliğe gömülen ve bu sessizliğin yalnızlaştırdığı kahramanların yola çıkma hayalleri ve istekleri kendilerini saran/sarmalayan cam fanusu -onduramadıkları kötücül dünya da denebilir- kırarak aydınlık bir dünyaya kapı aralamanın özlemiyle de açıklanabilir. Kitapta yer alan öykülerin bütününe bakıldığında yazar, gidişlerin nedenlerini ve sonuçlarını dile getirmekle birlikte karakterlerinin kurtuluş umudunu yol/yolculuk imgesiyle dışa vurmaktadır.

\section{Kaynaklar}

Adler, Alfred (2017). İnsanı Tanıma Sanatı, Çev. Kamuran Şipal, İstanbul: Say Yayınları.

Bakhtin, Mikhail (2001). Karnavaldan Romana-Edebiyat Teorisinden Dil Felsefesine Seçme Yazılar-, Çev. Cem Soydemir, İstanbul: Ayrıntı Yayınları.

Barbarosoğlu, Nalan (1996). Ne Kadar da Güzeldir Gitmek, İstanbul: Oğlak Yayınevi.

(2009). Yol Işılkları, İstanbul: Everest Yayınları.

Campbell, Joseph (2013). Kahramanın Sonsuz Yolculuğu, Çev. Sabri Gürses, İstanbul: Kabalcı Yayınc1lı.

Cebecioğlu, Ethem (2009). Tasavouf Terimleri ve Deyimleri Sözlüğü, İstanbul: Ağaç Kitabevi Yayınları.

Chatman, Seymour (2009). Öykü ve Söylem: Filmde ve Kurmacada Anlatı Yapısı, Çev. Özgür Yaren, İstanbul: De Ki Basım Yayım.

Çelik, Behçet (Aralık 2009). "Karanlığın İçindeki Işı1”, (Erişim tarihi: 25 
Haziran 2017) http://kitap.radikal.com.tr/makale/haber/karanligin_ icindeki_isik-60048.

Eliade, Mircea (1994). Ebedî Dönüş Mitosu, Çev. Ümit Altuğ, Ankara: İmge Kitabevi.

Iş1k, İhsan (2004). Türkiye Yazarlar Ansiklopedisi-1, Ankara: Elvan Yayınları.

Jung, Carl Gustav (2007). İnsan ve Sembolleri, Çev. Ali Nahit Babaoğlu, İstanbul: Okuyan Us Yayınlar1.

Kolcu, Ali İhsan (2015). Öykü Sanatı, Erzurum: Salkımsöğüt Yayınları.

Lekesiz, Ömer (2006). Kuramdan Uygulamaya Öykü Yazıları, İstanbul: Selis Kitaplar.

Moran, Berna (1997). "Üstkurmaca Olarak Kara Kitap”, Türk Romanına Eleştirel Bir Bakış, İstanbul: İletişim Yayınları, s. 93-104.

Proop, Vladimir (1985). Masalın Biçimbilimi, Çev. Mehmet Rifat ve Sema Rifat, İstanbul: Bilim/Felsefe/Sanat Yayınları.

Sambur, Bilal (2005). Bireyselleşme Yolu Jung'un Psikoloji Teorisi, Ankara: Elis Yayınları.

Sarıçiçek, M. (2013). Modern Kahramanın Mitolojik Yolculuğu, Kayseri: Kardeşler Ofset.

Tosun, Necip (2015). "Nalan Barbarosoğlu: Şiirsel Melankoli”, Günümüz Öyküsü, İstanbul: Dedalus Kitap, s. 143-152.

Uslu, Ahmet (2017). “Nalan Barbarosoğlu'nun Hikâyelerinde Biçim Olarak Melankoli”, Akademik Bakı̧s Dergisi 60, s. 350-366.

Yalçınkaya, Şerife (2007). "Yol Metaforu ve Klasik Türk Edebiyatında Arayış Yolculukları”, Türk Dili ve Edebiyatı Araștırmaları Dergisi 13, s. 251260.

\section{Sonnotlar}

1 Kitapta yer alan öykülerin çoğunda olaylar ve durumlar adı verilmeyen karakterler çevresinde döner. Bu belirsizlik ve kimliksizlik hâli Barbarosoğlu öykülerinin başat özelliğidir. Yazar bu bağlamda öykü kişilerinin hayatından kesitler sunarken onların kimliksizliğini bir sorunsal içinde dikkatlere sunar. Yol ve yolculuk arzusu da öykü kişilerinin bu kimlik arayışıyla ilişkili olarak düşünülebilir. 